\title{
Assessment of academic departments efficiency using data envelopment analysis
}

Salah R. Agha, Ibrahim Kuhail, Nader Abdelnabi, Mahmoud Salem, Ahmed Ghanim Islamic University-Gaza (GAZA STRIP) aghasn@yahoo.com; kuhail@gmail.com;nader12@,hotmail.com;salem20@hotmail.com; ghanim87@yahoo.com

\section{Abstract:}

Purpose: In this age of knowledge economy, universities play an important role in the development of a country. As government subsidies to universities have been decreasing, more efficient use of resources becomes important for university administrators. This study evaluates the relative technical efficiencies of academic departments at the Islamic University in Gaza (IUG) during the years 2004-2006.

Design/methodology/approach: This study applies Data Envelopment Analysis (DEA) to assess the relative technical efficiency of the academic departments. The inputs are operating expenses, credit hours and training resources, while the outputs are number of graduates, promotions and public service activities. The potential improvements and super efficiency are computed for inefficient and efficient departments respectively. Further, multiple linear -regression is used to develop a relationship between super efficiency and input and output variables.

Findings: Results show that the average efficiency score is $68.5 \%$ and that there are 10 efficient departments out of the 30 studied. It is noted that departments in the faculty of science, engineering and information technology have to greatly reduce their laboratory expenses. The department of economics and finance was found to have the highest super efficiency score among the efficient departments. 
Finally, it was found that promotions have the greatest contribution to the super efficiency scores while public services activities come next.

Research limitations/implications: The paper focuses only on academic departments at a single university. Further, DEA is deterministic in nature.

Practical implications: The findings offer insights on the inputs and outputs that significantly contribute to efficiencies so that inefficient departments can focus on these factors.

Originality/value: Prior studies have used only one type of DEA (BCC) and they did not explicitly answer the question posed by the inefficient departments "Which of the resources should be given priority so that these inefficient DMUs become efficient?". This study uses both (BCC) and (CCR) in addition to relating efficiencies to input and output variables.

Keywords: data envelopment analysis, performance, higher education, academic, efficiency

\section{Introduction}

Higher education is the backbone of development and economic growth in any country. Given that the academic institutions are responsible for the capacity building required for a country's long-term plans, the educational system in particular, is one of the pillars a country depends on to increase its productivity and thus efficiently implement its strategic plans. There is no doubt that an efficient system of institutions of higher education is crucial to providing the necessary profession manpower of scientists, engineers, doctors, and teachers. Therefore, there is a need to assess the efficiency of the educational institutions, and whether the high cost being spent on them is worthwhile. Further, it is necessary to have standards by which all educational institutions could be questioned through the evaluation of efficiency of using resources (Inputs) and achieving the goals (Outputs) for which these resources were spent. 
From 1948 to 1967, there were no higher education institutions in Gaza Strip, therefore most of Gazan students used to study at Egyptian universities without any obstacles. After Gaza Strip was occupied in 1967, Gazans found great difficulties in sending their sons and daughters to study abroad. Hence, the idea of establishing the Islamic University was coined.

The Islamic University in Gaza (IUG) was established in 1978. Till 1991, the Islamic University was the sole university in Gaza Strip. It started with three faculties: Faculty of Shariah (Islamic Law), Faculty of Ussoul Eldeen (religious foundation), and the Faculty of Arabic language, which later became the Faculty of Arts. Due to the need of Palestinian society for other disciplines, Faculty of Education, Faculty of Commerce and Faculty of Sciences were established in 1980. In 1991, the Faculty of Engineering was established, and at the beginning of the academic year 19921993, the Faculty of Nursing was established and the Faculty of medicine witnessed its birth at the beginning of the academic year 2006-2007.

Throughout those years, IUG witnessed a remarkable growth in its academic and administrative staff, as well as in its students and graduates. This growth was associated with the expanding of its facilities, units, laboratories and services in the field of scientific research, community development, in addition to its national, regional and international relations.

Data Envelopment Analysis (DEA) is a relatively new data-oriented approach for evaluating the technical efficiency of a set of peer entities called Decision Making Units (DMUs). DEA provides a single measure and easily deals with multiple inputs and multiple outputs. Since the DEA technique was first developed, it has been widely applied to industries as diverse as health care (Bhat, Verma, \& Reuben, 2001; Jacobs, Smith, \& Street, 2006), Banking (Hassan \& Sanchez, 2007), and transportation (Pathomsiri, 2006) and many other industries and organizations. Further, DEA-approach has proved especially valuable in cases where we have nonmarketed inputs or outputs and/or cannot be derived or agreed upon among different DMUs. In this study, DEA is used to assess the efficiencies of the academic departments (DMUs) at IUG.

This paper is organized as follows: section 2 gives a brief review of the relevant literature and specifically variables used as inputs and outputs in similar studies. Section 3 gives a background on the Decision making Units (DMUs) used in this 
study and describes the way these DMUs were selected. Variable selection is given in section 4. Section 5 describes the models used in the study. Results and discussion are given in section 6 . Finally, section 7 concludes the paper.

\section{Literature review}

In recent years, several studies have analyzed performance and efficiency in educational institutions using DEA approach. Each study differs in its scope, DMUs, and variables. An overview of the related studies is given. It is noted that these studies can be divided into two types. The first deals with efficiencies of universities while the second one deals with efficiencies of academic departments within universities and this is the focus of this study. The study of Abbott and Doucouliagos (2003) is one of the first type. It used data envelopment analysis to estimate technical and scale efficiency of individual Australian universities. Measures of teaching output include the number of equivalent full-time students, the number of post-graduate and under-graduate degrees enrolled, as well as the number of post-graduate degrees conferred and the number of under-graduate degrees conferred. The input measures include the total number of academic staff, the number of non-academic staff, expenditure on all other inputs other than labor inputs, and the value of non-current assets. The technical and scale efficiency results suggest that the Australian universities are operating at a fairly high level of efficiency relative to each other, although there is a room for improvement in several universities. This study is included here due to the fact that it uses similar variables like those used in the second type.

As for the second type of studies, Lopes and Lanzer (2002) used data envelopment analysis and fuzzy sets to assess the performance of academic departments at Federal University of Santa Catarina in Brazil. The model applied to a set of fiftyeight departments showed fifteen with low performance. In addition, Moreno and Tadepalli (2002) assessed academic department efficiency of a public university. Data envelopment analysis is proposed for evaluating the efficiency of 42 academic departments at a public university. The inputs are faculty salaries, staff salaries, operational budget, equipment budget, and building space allocated to each academic unit while the outputs are number of graduates, number of undergraduates, full time equivalents produced, student credit hours generated, 
and amount of grants awarded. The study results show 22 of departments were relatively efficient.

Finally, Kao and Hung (2006) used data envelopment analysis to assess the relative efficiency of the academic departments at National Cheng Kung University in Taiwan. The outputs considered are total credit-hours, publications, and external grants; and the inputs utilized by the departments are personnel, operating expenses, and floor space. An assurance region is constructed by the top administrators of the university to confine the flexibility in selecting the virtual multipliers in DEA.

As it can be seen, each study differs in its scope, DMUs, and variables. These studies are summarized as shown in Table 1. It is noted here that most of these studies used only one type of DEA (BCC). In addition, most of these studies, did not explicitly answer the question posed by the inefficient departments" Which of the resources should be given priority so that these inefficient DMUs become efficient?" In other words, most of these studies did not suggest where to start improving the efficiency. Therefore, this study uses not just one DEA model but it used the two DEA models in order to determine which of these models better represent the system. Further, the current study models the efficiency as a function of inputs and outputs, thus, inefficient DMUs can select the input that contributes more to their efficiencies. It is further noted that most of the studies were performed in developed countries. Therefore, it is imperative to use and diffuse these technologies in the developing countries. Clearly, the differences among these countries lead to different input and output variables due to the nature of departments, their interdependence, and availability of data. Due to the high subjectivity of research evaluation and avenues of publications, number of promotions was considered as a factor in this study. Since it is the first study, and due to the difficulty of obtaining some needed qualitative data, authors attempted to use only quantitative data just as a start so departments would make sure in the future to make available whatever qualitative data deemed to be necessary to perform future studies. It is not inconceivable that the absence of efficiency studies in the developing countries may be attributed to the following reasons. First: data availability regarding some of the common criterion used in developed countries. Second: the inappropriateness of some of these criteria to be used in developing countries. Therefore, the purpose of this study is three- fold. First: to bridge the 
gap existing in the literature, Second: introduce this methodology to developing countries and in the mean time find the relevant factors affecting the efficiency or at least thought to affect it based on experts' opinions.

\begin{tabular}{|c|c|c|}
\hline Author (s) & I nputs & Outputs \\
\hline $\begin{array}{l}\text { Lope and Lanzer } \\
\qquad(2002)\end{array}$ & $\begin{array}{ll}\text { - } & \text { Faculty salaries } \\
\text { - } & \text { Staff salaries } \\
\text { - } & \text { Operational budget } \\
\text { - } & \text { Equipment budget } \\
\text { - } & \text { Building space allocated to } \\
& \text { each academic unit }\end{array}$ & $\begin{array}{ll}\text { - } & \text { Number of graduate majors } \\
\text { - } & \text { Number of undergraduate } \\
\text { majors } \\
\text { - } \quad \text { Full time equivalents produced } \\
\text { - } & \text { Amodent credit hours generated } \\
& \text { Amount of grants awarded }\end{array}$ \\
\hline $\begin{array}{c}\text { Moreno and } \\
\text { Tadepalli ( 2002) }\end{array}$ & $\begin{array}{ll}\text { - } & \text { Faculty salaries } \\
\text { - } & \text { Staff salaries } \\
\text { - } & \text { Operational budget } \\
\text { - } & \text { Equipment budget } \\
\text { - } & \text { Space allocated in square } \\
& \text { feet. }\end{array}$ & $\begin{array}{l}\text { - } \quad \text { Graduates. } \\
\text { - } \quad \text { Under-graduates } \\
\text { - } \quad \text { Studime equivalents prodit hours } \\
\quad \text { generated. } \\
\text { - } \\
\quad \text { Amount of grants awarded. }\end{array}$ \\
\hline $\begin{array}{l}\text { Abbott and } \\
\text { Doucouliagos } \\
(2002)\end{array}$ & $\begin{array}{l}\text { - Total number of academic } \\
\text { staff } \\
\text { - The number of non-academic } \\
\text { staff } \\
\text { - Expenditure on all other } \\
\text { inputs }\end{array}$ & $\begin{array}{l}\text { The number of equivalent full- } \\
\text { time students } \\
\text { - The number of post-graduate } \\
\text { - Under-graduate degrees } \\
\text { enrolled } \\
\text { - The number of post-graduate } \\
\text { degrees conferred } \\
\text { The number of under-graduate } \\
\text { degrees conferred. }\end{array}$ \\
\hline $\begin{array}{c}\text { Kao and Hung } \\
(2006)\end{array}$ & $\begin{array}{ll}\text { - } & \text { Personnel } \\
\text { - } & \text { Operating expenses } \\
\text { - } & \text { Floor space. }\end{array}$ & $\begin{array}{ll}\text { - } & \text { Credit-hours } \\
- & \text { Publications } \\
\text { - } & \text { External grants }\end{array}$ \\
\hline
\end{tabular}

Table 1. "Input and Output Variables in Previous Studies Using DEA".

\section{Decision Making Units “DMUs"}

The Islamic University of Gaza (IUG) has ten faculties awarding BA. , B.Sc., MA, M.Sc., MBBS, and higher diplomas in a variety of disciplines. The ten faculties have 37 departments that offer 44 bachelor programs.

Departments that have no graduates over the study period are excluded such as mathematics/statistics, optometry and biotechnology departments and faculty of medicine. As for the faculty of education, it was considered as one DMU because of the huge overlap among its departments especially in the faculty requirements courses. For the same reason, economics department is merged with political sciences; and journalism and mass communication departments were also treated as one department. Eventually, considering all above, the research sample includes 30 DMUs spanning nine of the IUG faculties as shown in Table 2. 


\begin{tabular}{|c|c|}
\hline Faculty & DMUs \\
\hline $\begin{array}{l}\text { Ussoul Eldeen } \\
\text { (Religious Foundation) }\end{array}$ & $\begin{array}{l}\text { 1. General Ussoul Eldeen (Religious } \\
\text { Foundation) }\end{array}$ \\
\hline Shariah and law & 2. Islamic Shariah. \\
\hline \multirow{7}{*}{ Arts } & 3. Arabic \\
\hline & 4. English \\
\hline & 5. Geography \\
\hline & 6. Journalism \& Information \\
\hline & 7. Public Relations and Advertisements \\
\hline & 8. Social Work \\
\hline & 9. History and Archeology \\
\hline Education & 10. Education \\
\hline \multirow{4}{*}{ Commerce } & 11. Business Administration \\
\hline & 12. Economics and Political Sciences \\
\hline & 13. Accounting \\
\hline & 14. Banking and Finance \\
\hline \multirow{8}{*}{ Science } & 15. Chemistry \\
\hline & 16. Mathematics \\
\hline & 17. Physics \\
\hline & 18. Biology \\
\hline & 19. Medical Technology \\
\hline & 20. Environment and Earth Science \\
\hline & 21. Mathematics-Computer \\
\hline & 22. Chemistry-Biochemistry \\
\hline Nursing & 23. General Nursing \\
\hline \multirow{2}{*}{ I nformation Technology “IT” } & 24. Computer Science \\
\hline & 25. Information Technology System \\
\hline \multirow{5}{*}{ Engineering } & 26. Civil Engineering \\
\hline & 27. Architectural Engineering \\
\hline & 28. Electrical Engineering \\
\hline & 29. Computer Engineering \\
\hline & 30. Industrial Engineering \\
\hline
\end{tabular}

Table 2. "Decision Making Units".

\section{Variables selection}

The selection of input and output variables for evaluating academic departments' performance using DEA has been discussed in several studies. There are at least two difficulties in selecting the variables. One is the availability of data. For example, some scholars suggest using the salary of the first job as a measure of the achievement of teaching. Unfortunately, these data are difficult to obtain. Further, different professions have different salary standards. The other difficulty is 
the measurement of quality, there is a lack of a common base for comparing the quality of research works and subjectivity is usually involved. Since the objective of this paper is to investigate the work load and effort devoted to teaching and research, only quantifiable measures are considered. To obtain input and output variables in this study, a preliminary list was composed using all input and output variables used in the literature. This list was shown to senior university who were asked to give their feedback whether the list is reasonable. Further, they were asked to add/delete/combine variables. Based on these responses, a refined list was compiled and shown again and again to university administration until a consensus was reached on what variables should be used to better represent the efficiency of the system (department). Thus, a final list of variables was obtained. These variables include Operating Expenses (OE), Training Resources (TR) and Credit Hours $(\mathrm{CH})$ as inputs, while the number of Graduates (GR), Promotions (PROM) and Public Services Activities (PSA) are selected as outputs for the current study. The following paragraphs give more details about these measures.

Operating Expenses (OE) of each department is the ongoing operational expenses such as administrative cost and stationery. Credit Hours $(\mathrm{CH})$ is the actual hours offered by each department. Finally, Training Resources (TR) is the fixed cost of laboratories, facilities, and special assistance units from which the graduates benefited over the three-year study period.

On the other hand, Graduates (GR) is the number of students who graduated during the study period, while promotions (PROM) is the number of promotions attained by the academic staff of each department over the period of study 20042006. The final output is Public Service Activities (PSA) which includes the number of officially documented workshops, conferences, training courses and other extracurricular activities by the teaching staff of each department, that are officially documented at the university. A summary of these variables is given in Table 3 .

To ensure meaningful efficiency scores, the number of departments (DMUs) must be large enough relative to the number of input and output variables. A rule of thumb is given by Banker, Charnes and Cooper (1984) as [ $s+m \leq n / 3]$, where $s$ is the number of output variables, $m$ the number of input variables, and $n$ the number of DMUs. In this research, the number of input and output variables is $(3+3)$, which is less than one-third of the number of DMUs. It is important though 
to note that this rule of thumb is not universally accepted and still the research sample size is large enough when using another rule which requires that the number of DMUs $>=2 * s^{*} m=18$ was considered which is less than the 30 DMUs used in this study.

\begin{tabular}{|c|c|}
\hline Variable & Source of data \\
\hline $\begin{array}{l}\text { 1. Operating Expenses (OE): equipments, } \\
\text { stationery and other materials. }\end{array}$ & $\begin{array}{l}\text { Questionnaire and } \\
\text { department. }\end{array}$ \\
\hline $\begin{array}{l}\text { 2. Load in Hours ( LH): load hours minus overlap } \\
\text { hours between departments. }\end{array}$ & $\begin{array}{l}\text { Questionnaire and registration \& } \\
\text { admission unit. }\end{array}$ \\
\hline $\begin{array}{l}\text { 3. Training Resources (TR): laboratories, } \\
\text { facilities, ceremonies and special assistance } \\
\text { units. }\end{array}$ & Technicians and financial department. \\
\hline $\begin{array}{l}\text { 4. Graduates (GR): number of students who } \\
\text { graduate over the three-year study period. }\end{array}$ & Planning and development deanship \\
\hline 5. Promotions (PRO): represented by promotions. & Scientific research deanship. \\
\hline $\begin{array}{l}\text { 6. Public Service Activities (PSA): number of } \\
\text { meetings, workshops, conferences, training } \\
\text { courses outside the approved hours and } \\
\text { extracurricular activities. }\end{array}$ & $\begin{array}{l}\text { Scientific research deanship, public } \\
\text { relations unit, university website and } \\
\text { information technology unit. }\end{array}$ \\
\hline
\end{tabular}

Table 3. "Data Collection Summary".

\subsection{Data collection}

After input and output variables were finalized, a data sheet was designed in such a way that the values of these variables are filled in by different departments and units. The values of research variables were obtained in three ways: first, questionnaires that were distributed to all heads of departments to obtain operating expenses and load hours of each department. Second, interviews with quality unit directors, faculties' deans and directors, heads of departments, technicians, planning and development deanship, public relations unit, admission and registration office, financial department, scientific research deanship, information technology unit and university president's office. Finally, university website, publications, and brochures were used in data collection. The methods used in collecting these study variables are shown in Table 3. As it is noted from Table 3, operating expenses were obtained from the financial department of the university, while load hours for each department were obtained from the admission and registration unit. As for training resources, it was obtained from the financial 
department along with the technicians in each department. The number of graduates in the period under study was obtained from the planning and development deanship in the university. The number of promotions attained in each department was directly obtained from scientific research deanship. Finally, number of public service activities offered by each department was obtained from scientific research deanship, public relations unit, department websites, and the information technology unit.

\begin{tabular}{|c|c|c|c|c|c|c|c|}
\hline \multirow[b]{2}{*}{ Faculty } & \multirow[b]{2}{*}{ DMU } & \multicolumn{3}{|l|}{ I nput } & \multicolumn{3}{|l|}{ Output } \\
\hline & & $\begin{array}{l}\text { OE } \\
\text { (\$) }\end{array}$ & $\begin{array}{l}\text { CH } \\
\text { (Hrs.) }\end{array}$ & $\begin{array}{l}\text { TR } \\
\text { (\$) }\end{array}$ & $\begin{array}{l}\text { GR } \\
\text { (Student) }\end{array}$ & $\begin{array}{l}\text { PROM } \\
\text { (Promotion) }\end{array}$ & $\begin{array}{l}\text { PSA } \\
\text { (Activities) }\end{array}$ \\
\hline \multirow{2}{*}{$\begin{array}{l}\text { Ussoul } \\
\text { Eldeen } \\
\text { (Religious } \\
\text { Foundation) } \\
\text { Shariah and } \\
\text { law }\end{array}$} & $\begin{array}{l}\text { General Ussoul } \\
\text { Eldeen.(Religious } \\
\text { Foundation) }\end{array}$ & 16005 & 314 & 30000 & 176 & 3.33 & 5.0 \\
\hline & Islamic Shariah. & 4527 & 756 & 0 & 176 & 1.00 & 11.0 \\
\hline \multirow{7}{*}{ Arts } & Arabic. & 4645 & 466 & 0 & 7 & 2.00 & 4.0 \\
\hline & English. & 4645 & 652 & 6000 & 47 & 0.67 & 6.7 \\
\hline & Geography. & 4645 & 277 & 5000 & 15 & 0.00 & 10.0 \\
\hline & $\begin{array}{l}\text { Journalism \& } \\
\text { Information. }\end{array}$ & 7741 & 287 & 60000 & 27 & 0.33 & 12.7 \\
\hline & $\begin{array}{l}\text { Public Relations } \\
\text { and Adv. }\end{array}$ & 1548 & 0 & 60000 & 28 & 0.00 & 12.7 \\
\hline & Social Work. & 3096 & 172 & 0 & 69 & 0.00 & 3.0 \\
\hline & \begin{tabular}{|l|} 
History and \\
Archaeology.
\end{tabular} & 4645 & 247 & 10000 & 24 & 1.00 & 3.0 \\
\hline Education & Education. & 22767 & 2595 & 35000 & 890 & 2.00 & 22.0 \\
\hline \multirow{4}{*}{ Commerce } & \begin{tabular}{|l|} 
Business \\
Administration.
\end{tabular} & 5000 & 309 & 10000 & 160 & 1.33 & 5.7 \\
\hline & \begin{tabular}{|l|} 
Economics and \\
Political \\
Sciences. \\
\end{tabular} & 3367 & 449 & 10000 & 59 & 0.67 & 10.7 \\
\hline & Accounting. & 2700 & 406 & 10000 & 26 & 0.67 & 12.0 \\
\hline & $\begin{array}{l}\text { Banking and } \\
\text { Finance. }\end{array}$ & 4500 & 0 & 10000 & 92 & 0.00 & 4.7 \\
\hline \multirow{8}{*}{ Science } & Chemistry. & 9333 & 261 & 372857 & 12 & 1.67 & 13.0 \\
\hline & Mathematics. & 4533 & 447 & 30000 & 5 & 1.00 & 4.7 \\
\hline & Physics. & 11000 & 426 & 285714 & 12 & 1.00 & 5.3 \\
\hline & Biology. & 8933 & 313 & 111429 & 12 & 0.33 & 10.0 \\
\hline & \begin{tabular}{|l|} 
Medical \\
Technology.
\end{tabular} & 10500 & 109 & 171429 & 38 & 0.67 & 7.0 \\
\hline & $\begin{array}{l}\text { Environment and } \\
\text { Earth Science. }\end{array}$ & 6000 & 175 & 51429 & 5 & 1.33 & 5.0 \\
\hline & $\begin{array}{l}\text { Mathematics- } \\
\text { Computer. }\end{array}$ & 4667 & 0 & 30000 & 11 & 0.00 & 3.0 \\
\hline & $\begin{array}{l}\text { Chemistry- } \\
\text { Biochemistry. }\end{array}$ & 4500 & 33 & 372857 & 8 & 0.00 & 3.0 \\
\hline Nursing & General Nursing. & 5760 & 395 & 80000 & 61 & 0.67 & 6.3 \\
\hline
\end{tabular}




\begin{tabular}{|c|c|c|c|c|c|c|c|}
\hline \multirow[b]{2}{*}{$\begin{array}{l}\text { Information } \\
\text { Technology }\end{array}$} & $\begin{array}{l}\text { Computer } \\
\text { Science. }\end{array}$ & 5533 & 321 & 120000 & 31 & 0.33 & 3.7 \\
\hline & $\begin{array}{l}\text { Information } \\
\text { Technology } \\
\text { System. }\end{array}$ & 4567 & 157 & 120000 & 29 & 0.00 & 3.7 \\
\hline \multirow{6}{*}{ Engineering } & $\begin{array}{l}\text { Civil } \\
\text { Engineering. }\end{array}$ & 12728 & 655 & 350000 & 142 & 0.67 & 7.7 \\
\hline & $\begin{array}{l}\text { Architectural } \\
\text { Engineering }\end{array}$ & 5455 & 357 & 90000 & 47 & 0.00 & 13.0 \\
\hline & $\begin{array}{l}\text { Electrical } \\
\text { Engineering. }\end{array}$ & 6408 & 464 & 371429 & 82 & 1.00 & 13.0 \\
\hline & $\begin{array}{l}\text { Computer } \\
\text { Engineering. }\end{array}$ & 6321 & 272 & 300000 & 110 & 0.33 & 7.0 \\
\hline & \begin{tabular}{|l} 
Industrial \\
Engineering.
\end{tabular} & 3637 & 184 & 370000 & 28 & 0.33 & 9.3 \\
\hline & Average & 6657 & 383 & 115771 & 81 & 0.74 & 7.92 \\
\hline
\end{tabular}

Table 4. "A 3-Year Average of Collected Data".

Table 4 shows the average of the collected variables. It is noticed from the table that the $\mathrm{CH}$ of Public Relations and Advertisement, Banking and Finance and Mathematics-Computer equal zero which means that their courses are covered by other departments. Further, training resources of I slamic Shariah, Arabic and social work departments equal zero which means that they did not have any laboratory facilities, workshops, during the study period. Finally, number of promotions ( PROM ) in Geography, Public Relations and Advertisement, Social Work, Banking and Finance, Mathematics-Computer, Chemistry-Biochemistry and Architecture equals zero which means that their academic staff did not have any promotion over the study period.

\section{DEA model}

As mentioned earlier, most of previous studies only used BCC model, in this research, both CCR and BCC input oriented models are used to select the model that fairly represents the behavior of the system in this study. Due to the fact that in a university environment, it is easier to control the inputs rather than the outputs, the DEA input oriented model is used to compute the efficiency of these departments. CCR assumes Constant Return to Scale (CRS) and BCC assumes Variable Return to Scale (VRS). The indicated optimization, then, assigns the evaluated DMU the most favorable weighting that the constraints allow (Banker et al., 1984; Charnes, Copper, Lewin, \& Seiford, 1994; Seiford, 1996; Asmilda, Paradib, Reesec, \& Tamb, 2004). 
Efficiency can be defined as weighted sum of outputs over weighted sum of inputs as shown in equation:

$$
\mathrm{h}_{\mathrm{o}}(u, v)=\sum_{\mathrm{r}} \mathrm{u}_{\mathrm{r}} \mathrm{y}_{\mathrm{ro}} / \sum_{\mathrm{r}} \mathrm{v}_{\mathrm{i}} \mathrm{x}_{\mathrm{io}}
$$

Using the inputs and outputs of this research, the equation will be as follows:

$$
\mathrm{h}_{\mathrm{o}}(u, v)=\frac{\mathrm{u}_{1}(\mathrm{GR})+\mathrm{u}_{2}(\mathrm{PROM})+\mathrm{u}_{3}(\mathrm{PSA})}{\mathrm{v}_{1}(\mathrm{OE})+\mathrm{v}_{2}(\mathrm{CH})+\mathrm{v}_{3}(\mathrm{TR})}
$$

Where:

h0: Relative efficiency of the department

GR: Average number of graduates.

PROM: Average number of promotions.

PSA: Average number of public service activities.

OE: Average operating expenses.

$\mathrm{CH}$ : Average Credit hours.

ur: Weight given to output, $r=1,2,3$

vi: Weight given to input, $i=1,2,3$

$$
\min \varepsilon \theta-\varepsilon\left(\sum_{i=1}^{3} s_{i}^{-}+\sum_{r=1}^{3} s_{r}^{+}\right)
$$

Subject to:

$$
\begin{gathered}
\sum_{j=1}^{30} x_{i j} \lambda_{j}+s_{i}^{-}=\theta x_{i o}, i=1,2,3 ; \\
\sum_{j=1}^{30} y_{r j} \lambda_{j}-s_{r}^{+}=y_{r o}, r=1,2,3 ; \\
\lambda_{j} \geq 0, \quad j=1,2, \ldots, 30
\end{gathered}
$$

For BCC model, the constraint $\sum_{i=1}^{30} \lambda_{i}=1$ is added.

Where:

$s_{i}^{-}$and $s_{r}^{+}$: are slack variables used to convert the inequalities to equivalent equations and $\varepsilon>0$ is an Archimedean element defined to be smaller than any positive real number. 
$\lambda_{j}:$ is the vector of intensity factors that defines the hypothetical DMU to which DMUjo is compared.

$\theta$ : is the radial (input reducing) measure of technical efficiency.

The efficiency of a decision making unit is measured relative to all other DMUs under the restriction that all DMUs lie on or below the efficient frontier, measures of relative efficiency are obtained.

Efficiency Measurement System (EMS) software version 1.3 (Scheel, 2000) is used in this research to measure the technical efficiency of the departments based on both CCR and BCC input oriented models. It is also used to find out the needed potential improvements of the inefficient departments in order to become $100 \%$ efficient.

\section{Results and discussion}

\subsection{CCR and BCC Results}

Table 5 shows the efficiency, the reference set(s) (benchmarks) for each DMU in addition to the average score of each faculty. Of the faculties only the Ussoul Eldeen, Shariah "Islamic law" and education are efficient. In the faculty of arts, which has an average score of $84.7 \%$, only four DMUs out of seven are efficient. Journalism and Information has the least score in the faculty of art which could be attributed to the relatively high input of training resources. Faculty of commerce has a score of $96.3 \%$. Meanwhile, Faculty of science has an average score of $64.6 \%$. All departments in faculty of science are inefficient which could be attributed to the fact that they have relatively large inputs in terms of training resources. Faculty of nursing is inefficient with a score of $45.7 \%$ resulting from the relatively low outputs.

Faculty of Information Technology has an average score of $9 \%$. It includes two DMUs; computer Science department which has a score of $24.8 \%$ due to relatively low outputs, and information technology systems department which has a score of $24.3 \%$ due to relatively high inputs and the fact that it is a newly established department and consequently the number of graduates is relatively low. Faculty of Engineering has an average score of $52 \%$ and its DMUs are inefficient since they 
have relatively high inputs in terms of training resources and the small number of promotions over the period under study.

\begin{tabular}{|c|c|c|c|}
\hline Faculty & Department “DMU" & $\begin{array}{l}\text { Efficiency } \\
\text { score(\% ) }\end{array}$ & $\begin{array}{l}\text { Reference } \\
\text { set }\end{array}$ \\
\hline Ussoul Eldeen & 1. General Ussoul Eldeen & 100 & 1 \\
\hline $\begin{array}{l}\text { Shariah and } \\
\text { law }\end{array}$ & 2. Islamic Shariah & 100 & 2 \\
\hline \multirow{7}{*}{ Arts } & 3. Arabic & 100 & 3 \\
\hline & 4. English & 53.3 & $\begin{array}{r}2,3 \\
5,11,13\end{array}$ \\
\hline & 5. Geography & 100 & 5 \\
\hline & 6. Journalism and Information & 58.2 & $\begin{array}{l}1,7,13 \\
14\end{array}$ \\
\hline & $\begin{array}{l}\text { 7. Public Relations and } \\
\text { Advertisements }\end{array}$ & 100 & 7 \\
\hline & 8. Social Work & 100 & 8 \\
\hline & 9. History And Archaeology & 75.6 & $1,3,7,13$ \\
\hline \multicolumn{2}{|r|}{ Average score } & \multicolumn{2}{|l|}{83.9} \\
\hline Education & 10. Education & 100 & 10 \\
\hline \multirow{4}{*}{ Commerce } & 11. Business Administration & 100 & 11 \\
\hline & $\begin{array}{l}\text { 12. Economics and Political } \\
\text { Sciences }\end{array}$ & 91.3 & $\begin{array}{l}2,7,11 \\
13,14\end{array}$ \\
\hline & 13. Accounting & 100 & 13 \\
\hline & 14. Banking And Finance & 100 & 14 \\
\hline \multicolumn{2}{|r|}{ Average score } & \multicolumn{2}{|l|}{97.8} \\
\hline \multirow{8}{*}{ Science } & 15. Chemistry & 86.4 & $1,3,7$ \\
\hline & 16. Mathematics & 58.1 & $3,7,13$ \\
\hline & 17. Physics & 37.2 & $1,3,7$ \\
\hline & 18. Biology & 32.6 & $\begin{array}{l}1,7,13 \\
14\end{array}$ \\
\hline & 19. Medical Technology & 58 & $1,7,14$ \\
\hline & 20. Environment and Earth Science & 98.4 & $1,3,7$ \\
\hline & 21. Mathematics-Computer & 34.4 & 7,14 \\
\hline & 22. Chemistry-Biochemistry & 9.0 & $7,10,11$ \\
\hline \multicolumn{2}{|r|}{ Average score } & \multicolumn{2}{|c|}{51.8} \\
\hline \multirow{3}{*}{$\begin{array}{c}\text { Information } \\
\text { Technology “I T" }\end{array}$} & 23. General Nursing & 45.7 & $2,3,7,11$ \\
\hline & 24. Computer Science & 24.8 & $2,3,7,11$ \\
\hline & 25. Information Technology System & 243 & $7,11,14$ \\
\hline \multicolumn{2}{|r|}{ Average score } & \multicolumn{2}{|l|}{24.5} \\
\hline \multirow{3}{*}{ Engineering } & 26. Civil Engineering & 37.3 & $7,11,14$ \\
\hline & 27. Architectural Engineering & 47.5 & $2,7,13,14$ \\
\hline & 28. Electrical Engineering & 65 & $2,3,7,11$ \\
\hline
\end{tabular}




\begin{tabular}{|c|c|c|c|}
\hline & 29. Computer Engineering & 61.6 & $7,11,14$ \\
\cline { 2 - 4 } & 30. Industrial Engineering & 51.8 & $2,3,7,11$ \\
\hline Average score & $\mathbf{5 2 . 6}$ \\
\hline Total average score & $\mathbf{6 8 . 3}$ \\
\hline
\end{tabular}

Table 5. "CCR results and reference sets".

Note in Table 6 that all inefficient DMUs have (reference sets) benchmarks. These DMUs are asked to learn how to transform their inputs to outputs. In other words, inefficient departments should adopt their benchmarks' policies and techniques in the production process. For example, as shown in Table 5, the reference sets of industrial engineering are Islamic Shariah, Arabic, public relations and advertising, business administration. Therefore, for industrial engineering to become efficient, it can learn best practices from these departments. Further, it is observed that DMU 7(Public relations and advertising) is the most recurring benchmark. It was referenced for 19 times, which means that there are 19 departments which could learn from DMU 7 best practices and thus become efficient. The same can be said about the other recurring benchmarks like DMUs 3 and 10 which are referenced for 10 times each. In other words, at least 10 inefficient departments can improve their efficiencies by learning from the methods and techniques adopted by these DMUs.

In summary, the average scores of DMUs range from $9 \%$ to $100 \% .10$ DMUs are efficient and 20 are inefficient. Chemistry-Biochemistry department has the least efficiency score of $9 \%$. The mean of the scores is $68.3 \%$ and the standard deviation is 0.3 .

In order to have more insights into the applicable model, BCC efficiencies were calculated and shown in Table 6. It is noted that BCC yields more efficient departments than CCR. These results are expected due to two reasons. First, theoretically CCR and BCC are ratios that share the same denominator while the numerator of BCC ratio is greater than the numerator in CCR ratio. Secondly, BCC relaxes the slack variables to be greater than zero and adding lambda constraint. It is known that relaxing a constraint in any problem would result in one of two scenarios. The first is that the original constraint is redundant and therefore, it would not affect the value of the objective function. While, the second scenario is that the original constraint is binding and therefore the objective function would deteriorate. Clearly, the second scenario is the one in action in our case. 


\begin{tabular}{|c|c|c|c|}
\hline Faculty & Department “DMU” & $\begin{array}{l}\text { Efficiency } \\
\text { score }\end{array}$ & Reference set \\
\hline Ussoul Eldeen & 1. General Ussoul Eldeen & $100 \%$ & 2 \\
\hline $\begin{array}{l}\text { Shariah and } \\
\text { law }\end{array}$ & 2. Islamic Shariah & $100 \%$ & 1 \\
\hline \multirow{7}{*}{ Arts } & 3. Arabic & $100 \%$ & 1 \\
\hline & 4. English & $85 \%$ & $2,3,8,12$ \\
\hline & 5. Geography & $100 \%$ & 0 \\
\hline & 6. Journalism and Information & $78 \%$ & $1,7,10,13,15$ \\
\hline & 7. Public Relations and Adv. & $100 \%$ & 5 \\
\hline & 8. Social Work & $100 \%$ & 1 \\
\hline & 9. History And Archaeology & $100 \%$ & 0 \\
\hline \multicolumn{2}{|r|}{ Average score } & \multicolumn{2}{|c|}{$94.7 \%$} \\
\hline Education & 10. Education & $100 \%$ & 2 \\
\hline \multirow{4}{*}{ Commerce } & 11. Business Administration & $100 \%$ & 2 \\
\hline & $\begin{array}{l}\text { 12. Economics and Political } \\
\text { Sciences }\end{array}$ & $100 \%$ & 4 \\
\hline & 13. Accounting & $100 \%$ & 1 \\
\hline & 14. Banking And Finance & $100 \%$ & 0 \\
\hline \multicolumn{2}{|r|}{ Average score } & \multicolumn{2}{|c|}{$100 \%$} \\
\hline \multirow{8}{*}{ Science } & 15. Chemistry & $100 \%$ & 7 \\
\hline & 16. Mathematics & $100 \%$ & 2 \\
\hline & 17. Physics & $63 \%$ & $7,15,16,21,25$ \\
\hline & 18. Biology & $100 \%$ & 0 \\
\hline & 19. Medical Technology & $93 \%$ & $1,7,15$ \\
\hline & $\begin{array}{l}\text { 20. Environment and Earth } \\
\text { Science }\end{array}$ & $100 \%$ & 0 \\
\hline & 21. Mathematics-Computer & $100 \%$ & 1 \\
\hline & 22. Chemistry-Biochemistry & $100 \%$ & 0 \\
\hline \multicolumn{2}{|r|}{ Average score } & \multicolumn{2}{|c|}{$94.5 \%$} \\
\hline Nursing & 23. General Nursing & $81 \%$ & $7,11,12,15,29$ \\
\hline \multirow{2}{*}{\begin{tabular}{|c|} 
Information \\
Technology “I T"
\end{tabular}} & 24. Computer Science & $90 \%$ & $12,15,16,25$ \\
\hline & 25. Information Technology Sys. & $100 \%$ & 2 \\
\hline \multicolumn{2}{|r|}{ Average score } & \multicolumn{2}{|l|}{$95 \%$} \\
\hline \multirow{5}{*}{ Engineering } & 26. Civil Engineering & $100 \%$ & $10,15,29$ \\
\hline & 27. Architecture & $100 \%$ & 0 \\
\hline & 28. Electrical Engineering & $100 \%$ & 0 \\
\hline & 29. Computer Engineering & $100 \%$ & 3 \\
\hline & 30. Industrial Engineering & $83 \%$ & $7,12,15,29$ \\
\hline \multicolumn{2}{|r|}{ Average score } & \multicolumn{2}{|c|}{$96.6 \%$} \\
\hline \multicolumn{2}{|r|}{ Total average score } & \multicolumn{2}{|c|}{$95.8 \%$} \\
\hline
\end{tabular}

Table 6. "BCC Results and Reference Sets". 


\begin{tabular}{|c|c|c|c|}
\hline Faculty & Department “DMU” & $\begin{array}{l}\text { Efficiency } \\
\text { score }\end{array}$ & Reference set \\
\hline Ussoul EIdeen & 31. General Ussoul Eldeen & $100 \%$ & 2 \\
\hline $\begin{array}{l}\text { Shariah and } \\
\text { law }\end{array}$ & 32. Islamic Shariah & $100 \%$ & 1 \\
\hline \multirow{7}{*}{ Arts } & 33. Arabic & $100 \%$ & 1 \\
\hline & 34. English & $85 \%$ & $2,3,8,12$ \\
\hline & 35. Geography & $100 \%$ & 0 \\
\hline & 36. Journalism and Information & $78 \%$ & $1,7,10,13,15$ \\
\hline & 37. Public Relations and Adv. & $100 \%$ & 5 \\
\hline & 38. Social Work & $100 \%$ & 1 \\
\hline & 39. History And Archaeology & $100 \%$ & 0 \\
\hline \multicolumn{2}{|r|}{ Average score } & \multicolumn{2}{|c|}{$94.7 \%$} \\
\hline Education & 40. Education & $100 \%$ & 2 \\
\hline \multirow{4}{*}{ Commerce } & 41. Business Administration & $100 \%$ & 2 \\
\hline & $\begin{array}{l}\text { 42. Economics and Political } \\
\text { Sciences }\end{array}$ & $100 \%$ & 4 \\
\hline & 43. Accounting & $100 \%$ & 1 \\
\hline & 44. Banking And Finance & $100 \%$ & 0 \\
\hline \multicolumn{2}{|r|}{ Average score } & \multicolumn{2}{|c|}{$100 \%$} \\
\hline \multirow{8}{*}{ Science } & 45. Chemistry & $100 \%$ & 7 \\
\hline & 46. Mathematics & $100 \%$ & 2 \\
\hline & 47. Physics & $63 \%$ & $7,15,16,21,25$ \\
\hline & 48. Biology & $100 \%$ & 0 \\
\hline & 49. Medical Technology & $93 \%$ & $1,7,15$ \\
\hline & $\begin{array}{l}\text { 50. Environment and Earth } \\
\text { Science }\end{array}$ & $100 \%$ & 0 \\
\hline & 51. Mathematics-Computer & $100 \%$ & 1 \\
\hline & 52. Chemistry-Biochemistry & $100 \%$ & 0 \\
\hline \multicolumn{2}{|r|}{ Average score } & \multicolumn{2}{|c|}{$94.5 \%$} \\
\hline Nursing & 53. General Nursing & $81 \%$ & $7,11,12,15,29$ \\
\hline \multirow{2}{*}{$\begin{array}{r}\text { I nformation } \\
\text { Technology “IT” }\end{array}$} & 54. Computer Science & $90 \%$ & $12,15,16,25$ \\
\hline & 55. Information Technology Sys. & $100 \%$ & 2 \\
\hline \multicolumn{2}{|r|}{ Average score } & \multicolumn{2}{|c|}{$95 \%$} \\
\hline \multirow{5}{*}{ Engineering } & 56. Civil Engineering & $100 \%$ & $10,15,29$ \\
\hline & 57. Architecture & $100 \%$ & 0 \\
\hline & 58. Electrical Engineering & $100 \%$ & 0 \\
\hline & 59. Computer Engineering & $100 \%$ & 3 \\
\hline & 60. Industrial Engineering & $83 \%$ & $7,12,15,29$ \\
\hline \multicolumn{2}{|r|}{ Average score } & \multicolumn{2}{|c|}{$96.6 \%$} \\
\hline \multicolumn{2}{|r|}{ Total average score } & \multicolumn{2}{|c|}{$95.8 \%$} \\
\hline
\end{tabular}

Table 6. "BCC Results and Reference Sets". 
Further, the values of CCR and BCC efficiencies are close to each other, which imply that either the CCR or BCC may be adopted for this research depending on the value of the correlation coefficient between DMUs size and CCR results. If Credit Hours $(\mathrm{CH})$ is considered to represent the DMU size, the correlation coefficient between DMUs size and CCR results equals 0.205 which means that there is no relation between efficiency score and DMU size. Further, even if the number of graduates is used to represent the DMU size, the correlation coefficient between the number of graduates and CCR results was still as low as 0.01 . So, the results of CCR model can be adopted to be the research result (Avkiran, 2002). In other words, there is no relationship between efficiency scores and DMU size. Equivalently said, the DMUs do not benefit from what is known in economics as economies of scale. Therefore, CCR results will be used in the analysis throughout the rest of the paper. Finally, the results obtained here are different than those in some of the previous studies. This could be attributed to the fact that some of these studies (Kao \& Hung, 2008) only used the BCC model and it was assumed to be the one representing the academic departments' performance.

\subsection{Potential improvements}

For inefficient departments to benefit from the study, the amounts by which these DMUs should decrease their inputs to become efficient are calculated using the CCR model. Figure 1 shows the actual and the targeted values of the operating expenses variable $(\mathrm{OE})$. In this study, the targeted value of a variable represents the amount to which a given DMU can decrease its consumption of that specific variable. It is noticed that mathematics, physic and biology departments in addition to departments in IT faculty, nursing and engineering to decrease their operating expenses by certain amounts to reach the targeted level shown in order to be efficient. As for Credit Hours, Figure 2 shows the actual and target values for this input. If inefficient departments can reduce their inputs to the corresponding target levels, then, they would become efficient. In general, departments in faculty of science and engineering need to reduce their inputs of Credit Hours in order to become efficient. Finally, as for the third input variable (TR), it is noticed in Figure 3 still that all departments belonging to faculties of science and engineering should decrease their usage of training resources and fixed assets incurred by the expensive labs. 


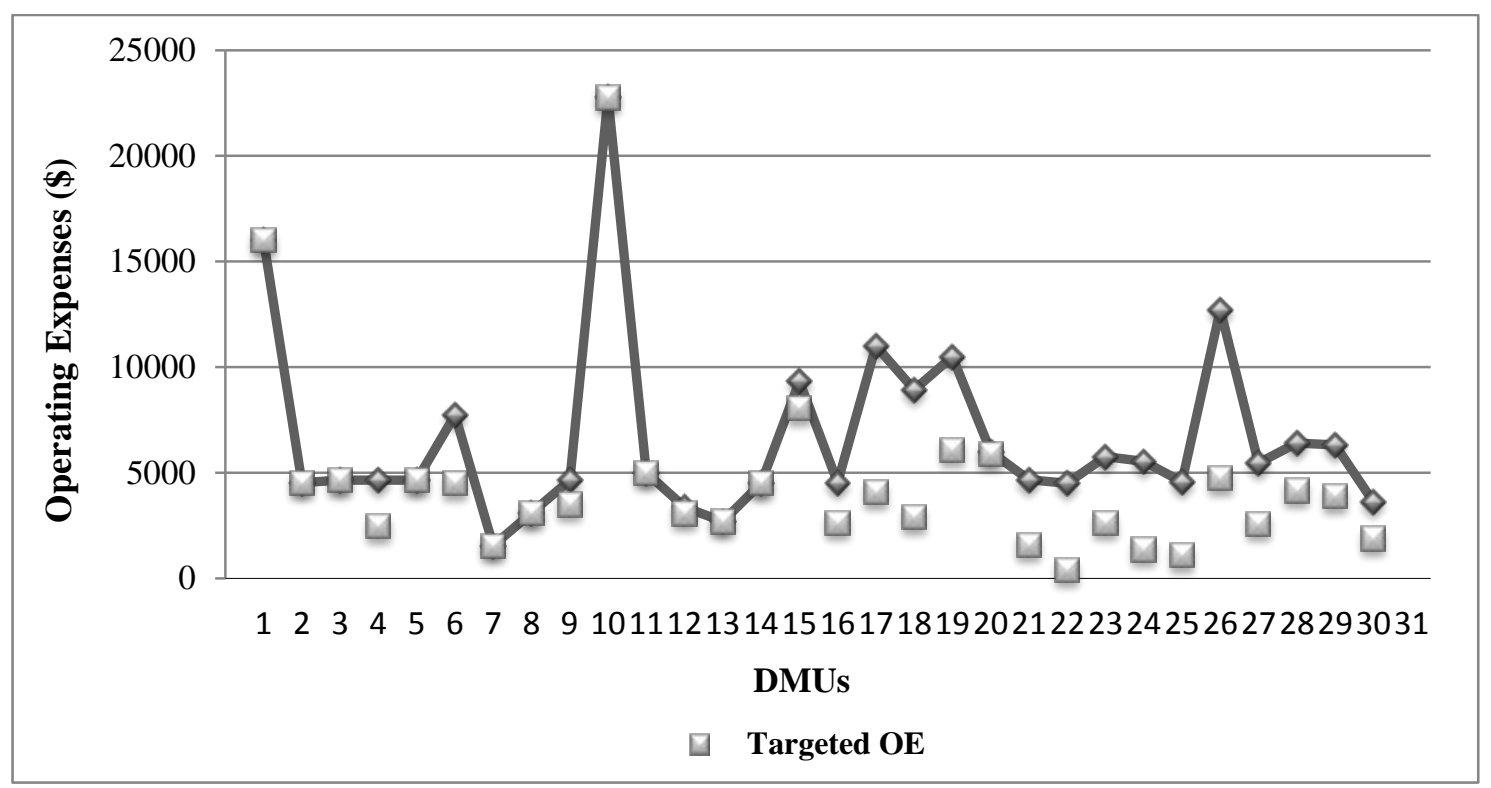

Figure 1. "Comparison between actual and targeted values of Operating Expenses".

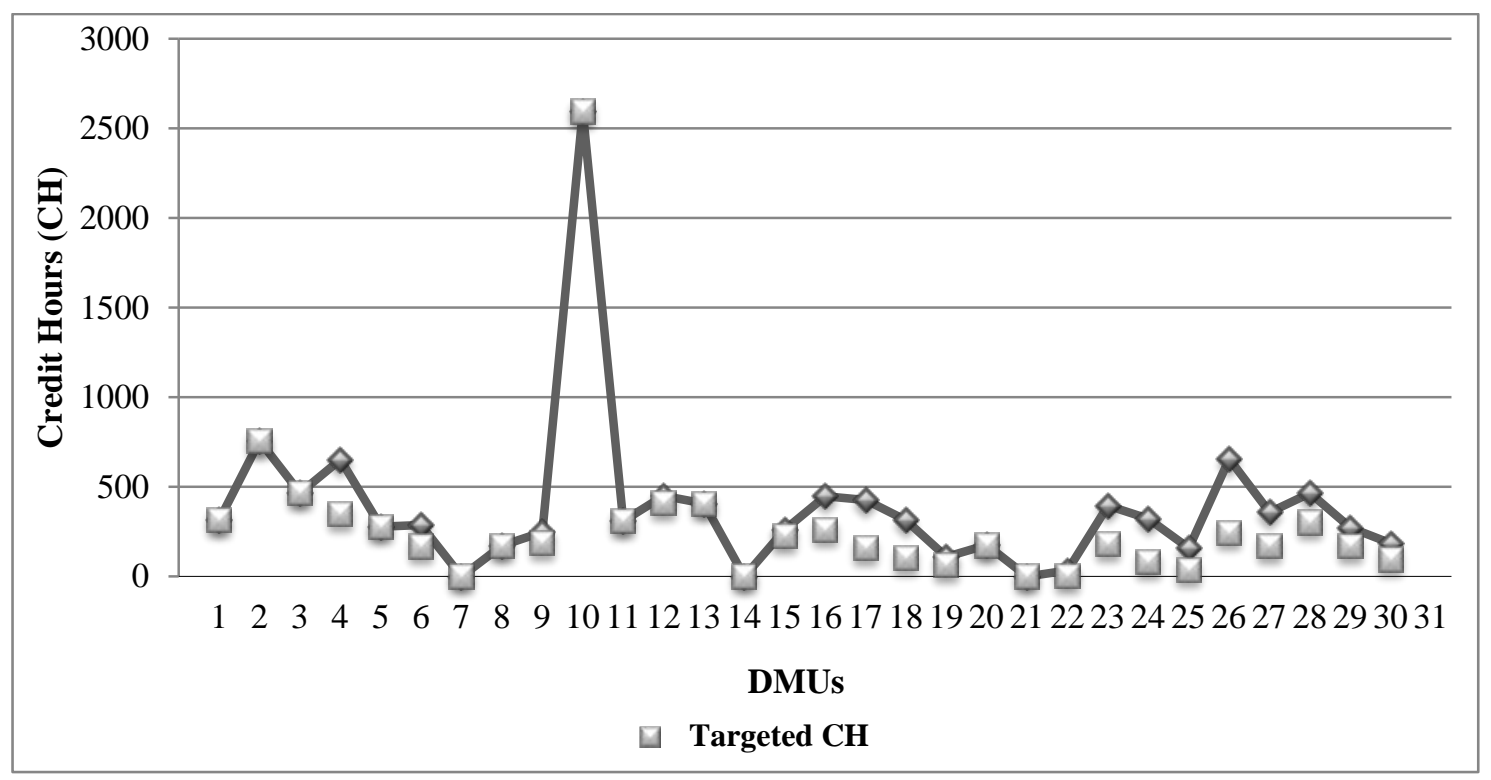

Figure 2. "Comparison between actual and targeted values of Credit Hours". 


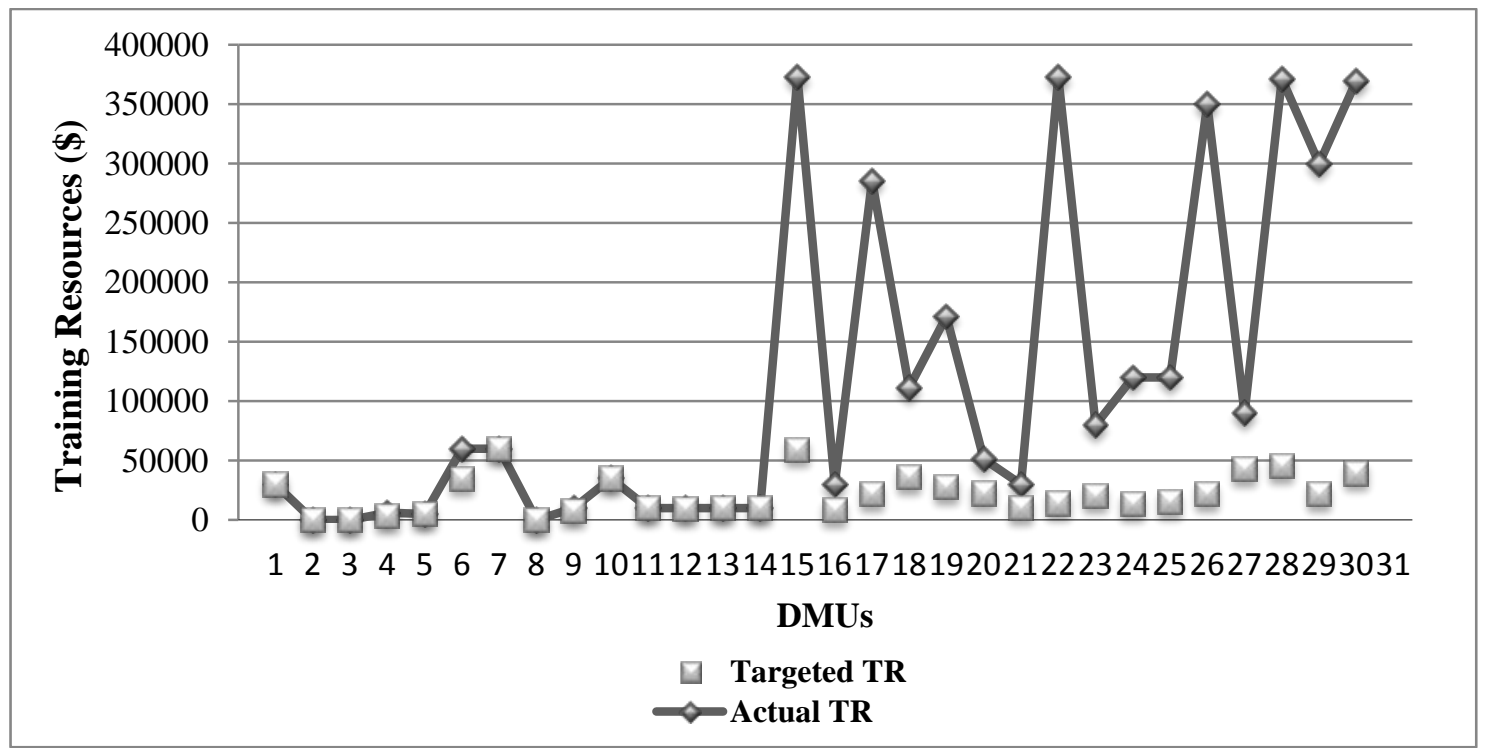

Figure 3. "Comparison between actual and targeted values of Training Resources".

\subsection{Super-efficiency analysis}

\begin{tabular}{lc}
\hline Department "DMU” & $\begin{array}{c}\text { Super-Efficiency } \\
\text { score\% }\end{array}$ \\
\hline 1. General Ussoul Eldeen. & 204.40 \\
2. Islamic Shariah. & 256.50 \\
3. Arabic. & 324.50 \\
4. Geograph. & 137.20 \\
5. Public Relations and Adv. & 785.50 \\
6. Social Work. & 172.30 \\
7. Education. & 110.40 \\
8. Business Administration. & 148.50 \\
9. Accounting. & 135.50 \\
10. Banking and Finance. & 1971.40 \\
\hline
\end{tabular}

Table 7. "Super-efficiency Scores of Efficient Departments".

Basic DEA models evaluate the relative efficiency of DMUs but do not allow ranking of the efficient DMUs themselves. Therefore, and for efficient departments to benefit from this study as well, super efficiency of efficient DMUs is evaluated by removing the inefficient DMUs in CCR results. Table 7 shows the super efficiency results. It is noticed that banking and finance department has the highest efficiency score of $1971 \%$ while the other efficient departments have a super- 
efficiency scores ranging from $110 \%$ to $785 \%$. Therefore efficient departments can benefit from this study by learning from more efficient ones. The next section shows how super efficiency scores relate to input and output variables.

\subsection{Regression model}

In order to help departments prioritize their goals and focus on the significant variables to become efficient, a multiple linear regression model that relates super efficiency scores to amounts of outputs is built. Equation (4) shows super efficiency in terms of outputs.

Super Efficiency $(O)=0.084+0.0086 G R+0.391 P R O M+0.08 P S A$

It is obvious that the PROM has the largest effect on super efficiency score, as indicated by its coefficient in equation (4), followed by PSA while GR has the least effect since it contributes to efficiency as much as one tenth of PSA. In other words, the effect of increasing the number of promotions by one is equivalent to increasing the number of graduates by ten. Therefore; inefficient departments should set their priorities by focusing on PROM first, then PSA and finally GR. The correlation coefficient of the resulting equation was found to be 0.9 which is pretty good. Figure 4 shows the relationship between the actual values of super efficiency versus predicted ones in terms of outputs.

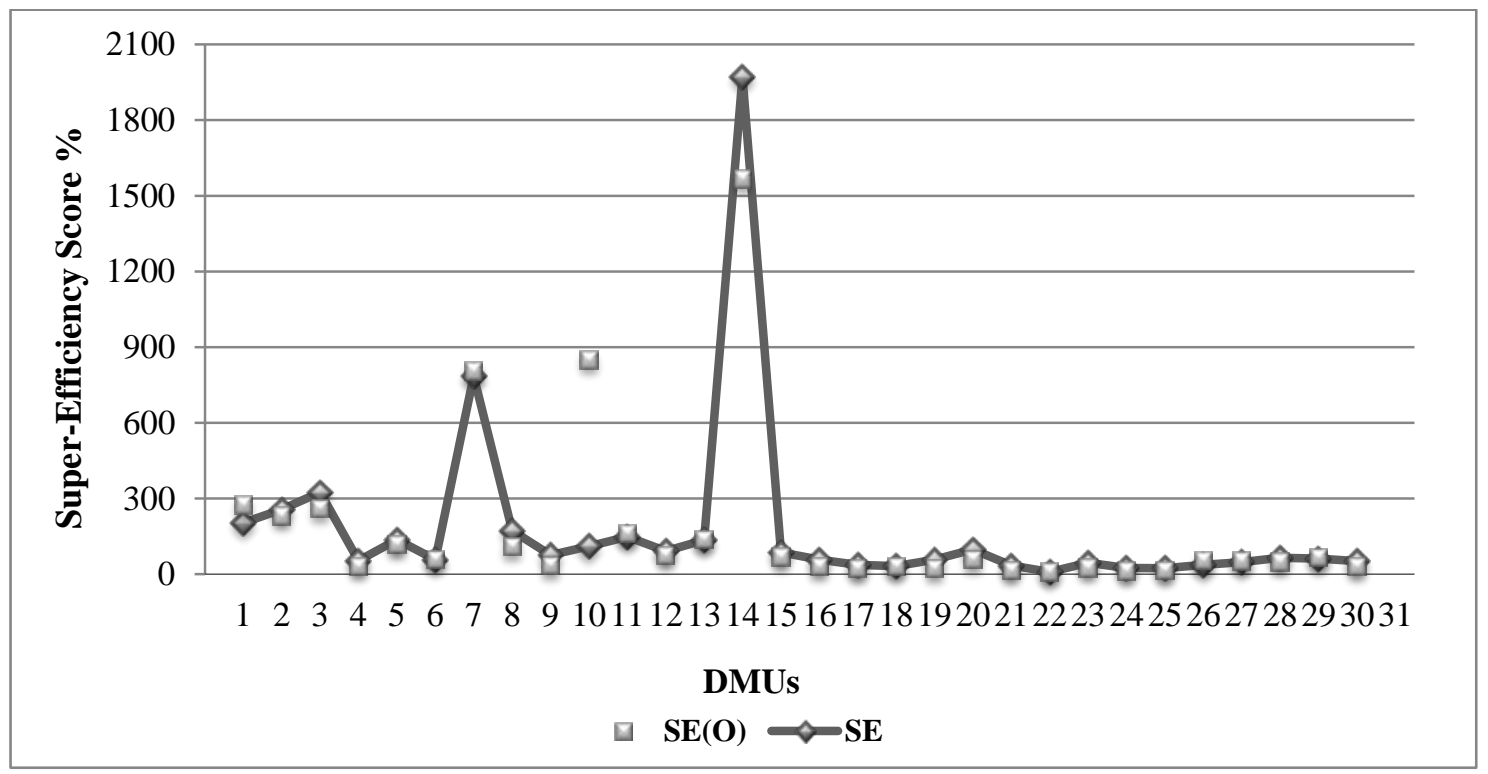

Figure 4. "Comparison between actual values of super efficiency and predicted ones using outputs only". 
In order to have a more sensitive prediction, both outputs and inputs were also included in the model. Clearly, as seen in Figure 5, the model performs better in terms of its prediction power and correlation coefficient which is 0.98. Super efficiency scores can be expressed as shown in equation (5):

Super Efficiency $(I, O)=1.9-0.000335 O E-0.0045 C R-1.95 e-5 T R+0.00945 G R+$ 0.371 PROM + 0.0641 PSA.

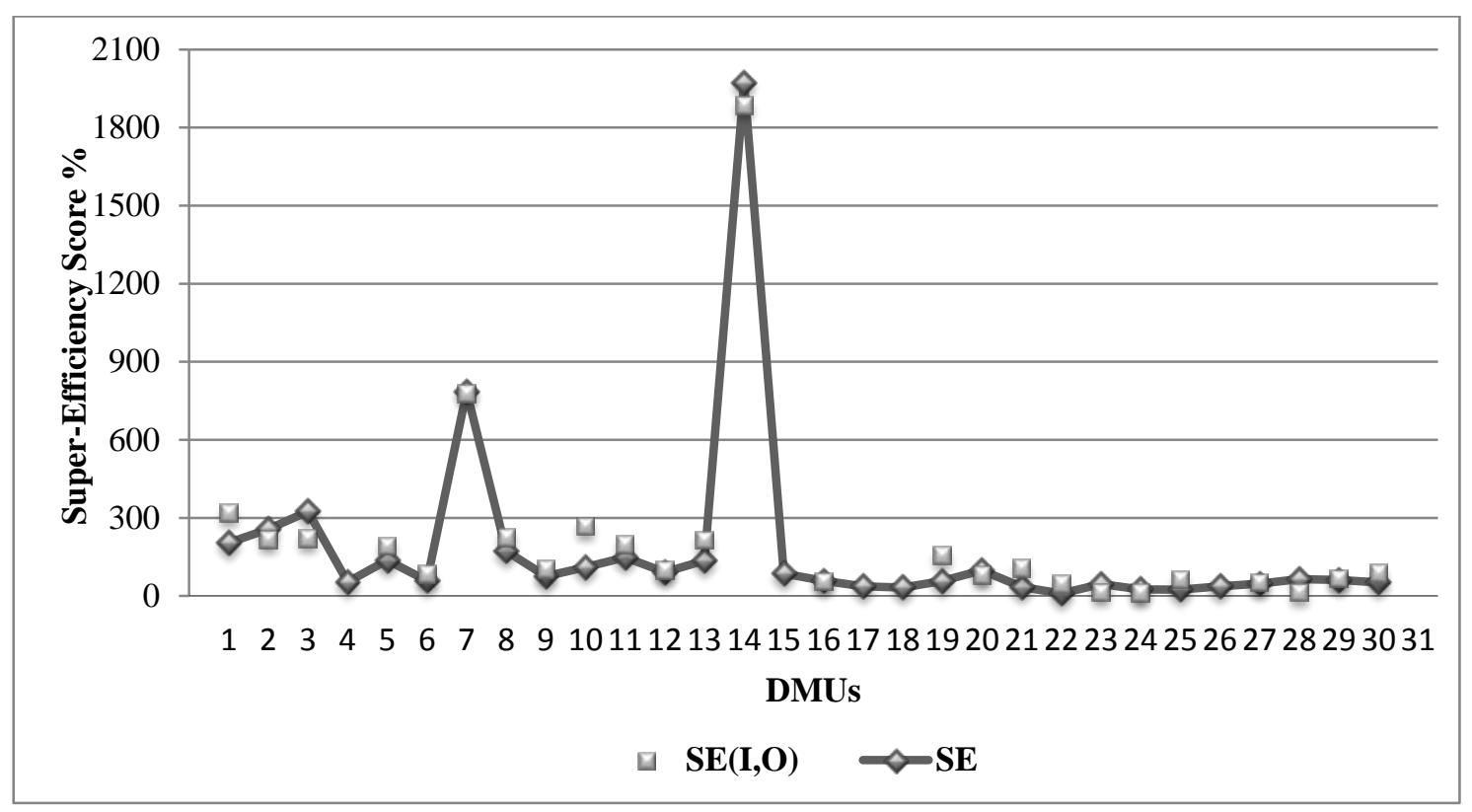

Figure 5. "Comparison between actual values of super efficiency and predicted ones using inputs and outputs".

It is clear that PROM. still has the largest contribution to super efficiency score as it was the case in model 1 , since it has the largest of 0.371 while TR has the lowest effect on the efficiency score. Moreover, PSA, GR, CH and OE do not have a large effect on efficiency scores because their weights are between 0.00033 and 0.064 and consequently they will not have a dramatic effect if they are changed since the problem is an input minimizing one. It is clear from equation (5) that a one unit increase in PROM is equivalent to increasing the number of students by more than 45 units. Meanwhile, PSA contributes reasonably high to the efficiency score, so it is in the interest of each department to increase its public service activities since it will enhance the output of a given department and certainly the efficiency score. 


\section{Conclusions}

This research used the input minimizing Data Envelopment Analysis approach to measure the technical efficiency of academic IUG departments. The DMUs of the research are 30 departments and the study covered the period (2004-2006). Six input and output variables are selected to represent these departments' efficiencies. Operating Expenses (OE), Credit Hours ( $\mathrm{CH})$, and Training Resources (TR) are used as inputs, while the outputs include number of Graduates (GR), Promotions (PROM), and Public Service Activities (PSA).

The results of CCR model have an average of $68.5 \% .10$ DMUs are $100 \%$ efficient in CCR. The potential improvements are then evaluated for each inefficient DMU. It was found that PSA needs the most improvement in outputs and TR needs the most improvement in inputs. Furthermore, the super-efficiency of efficient departments is measured for each department in order to identify the most efficient department and hence rank the rest of the efficient departments. Finally, and to help decision makers in the inefficient departments select the most promising variables to improve their efficiencies; a multiple linear model was built. The model expresses super efficiency as a function of inputs and outputs. Even in a better economic situation, this research will add a new tool to the decision makers' toolbox to effectively evaluate the performance of their institutions and to optimally manage their resources.

The fact that there are large differences in the efficiency scores of the different departments require that university administrators should allocate different amounts of different resources to the different departments.

Based on the above, it is recommended that university administration encourage and motivate its academic staff to focus more on publications which is mainly the criteria of promotion. Here comes the role of scientific research deanery to help those inefficient departments through more research grants and projects. This can be easily done due to the fact that scientific research grants are mainly centralized through the deanship. Worth mentioning here is the fact that the classical method of increasing cost efficiency through increasing number of graduates which is normally achieved through more aggressive recruitment efforts would not really be a very effective method to increase the technical efficiency of the corresponding departments. 
Further, university departments should make sure to collect and properly document the pertinent data in special data bases to make it easier to perform similar and more detailed studies in the future.

Although DEA is such a powerful tool, it should be noted here that this study is deterministic in nature. In other words, it does not deal with outliers. Therefore, it is recommended that other tools be used in future studies.

\section{References}

Abbott, M., \& Doucouliagos, C. (2003). The Efficiency of Australian Universities: A Data Envelopment Analysis. Economics of Education Review, 22(1), 89-97. doi: 10.1016/S0272-7757(01)00068-1

Asmilda, M., Paradib, J., Reesec, D. \& Tamb, F. (2007). Measuring overall efficiency and effectiveness using DEA. European Journal of Operational Research, 178(1), 305-321.

doi: 10.1016/j.ejor.2006.01.014

Avkiran, N. (2002). Productivity Analysis in the Service Sector. Australia: N. K. Avkiran Publisher.

Banker, R. D., Charnes, A., \& Cooper, W.W. (1984). Some Models for Estimating Technical and Scale Inefficiency in Data Envelopment Analysis. Management Science, 30(9), 1078-1092.

doi: $10.1287 / \mathrm{mnsc} \cdot 30.9 .1078$

Bhat, R., Verma, B. \& Reuben, E. (2001). Data Envelopment Analysis (DEA). J ournal of Health Management, 3(2), 309-328.

doi: 10.1177/097206340100300207

Charnes, A. Copper, W., Lewin, A. \& Seiford, L. (1994). Data Envelopment Analysis: Theory, Methodology, and Application. Kluwer Academic Publisher.

Hassan, K. \& Sanchez, B. (2007). Efficiency Determinants and Dynamic Efficiency Changes in Latin American Banking Industries. Networks Financial Institute Working Paper, No. 2007-WP-32. 
Jacobs, R., Smith, P. \& Street, A. (2006). Measuring Efficiency in Health Care: Analytic Techniques and Health Policy. Cambridge University Press. doi: $10.1017 /$ CBO9780511617492

Kao, C. \& Hung, H. (2008). Efficiency Analysis of University Departments: An Empirical Study. Omega, 36(4), 653-664. doi: 10.1016/j.omega.2006.02.003

Lopes, A., Lanzer, E. (2002). Data Envelopment Analysis-DEA And Fuzzy Sets to Assess The Performance of Academic Departments: A Study at Federal University Of Santa Catrina-UFSC. Pesquisa Operacional, 22(2), 217-230. doi: 10.1590/S0101-74382002000200008

Moreno, A. \& Tadepalli, R. (2002). Assessing Academic Department Efficiency a Public University. Managerial and Decision Economics, 23(7), 385-397. doi: $10.1002 / \mathrm{mde} .1075$

Pathomsiri, S. (2006). Assessment of Productive Efficiency of Airports. Dissertation at the University of Maryland - USA.

Scheel, H. (2000). Efficiency Measurement System Software "EMS", Version 1.3.0.

Seiford, L.M. (1996). Data Envelopment Analysis: the evolution of the state of the art (1978 - 1995). Journal of Productivity Analysis, 7(2-3), 99-137. doi: $10.1007 /$ BF00157037

Article's contents are provided on a Attribution-Non Commercial 3.0 Creative commons license. Readers are allowed to copy, distribute and communicate article's contents, provided the author's and Journal of Industrial Engineering and Management's names are included. It must not be used for commercial purposes. To see the complete license contents, please visit http://creativecommons.org/licenses/by-nc/3.0/. 